\title{
Outline
}

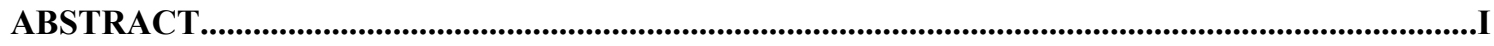

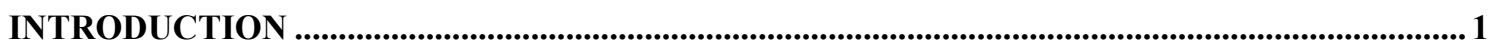

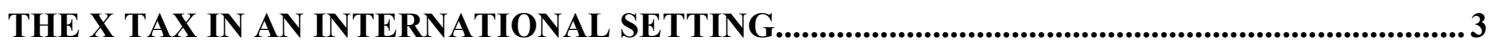

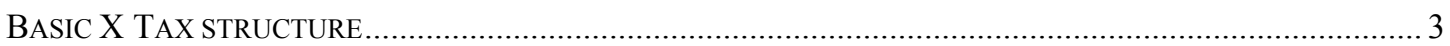

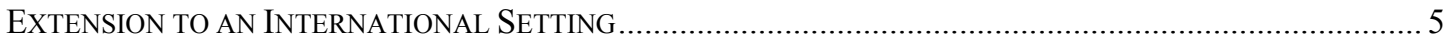

Two General Approaches: Origin- and Destination-Based Taxes............................................... 5

Economic Equivalence between the Approaches: The Basics ……................................................ 6

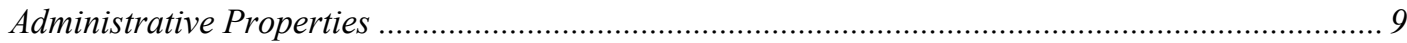

Supernormal Returns, Measurement Issues and Transfer Pricing Problems ................................... 12

TRANSITION AND TAX RATE CHANGES OVER TIME ......................................................16

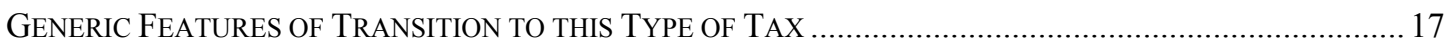

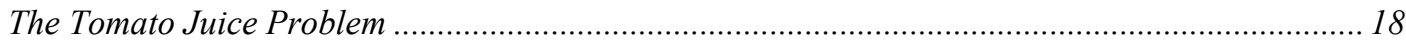

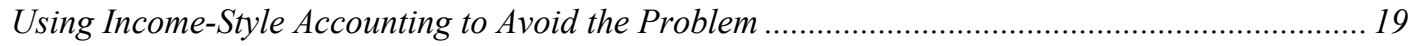

The Fundamental Problem of Rate Changes in a Destination TaX …………............................ 21

A REMEDY FOR THE TRANSFER-PRICING PROBLEM IN AN ORIGIN-BASED X TAX ..... 25

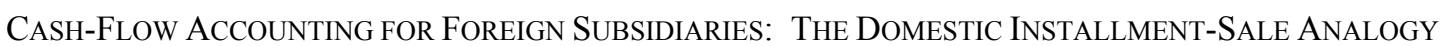

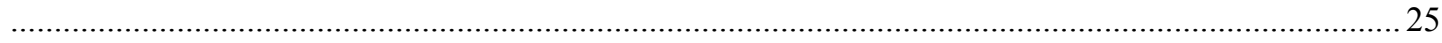

APPlying THE APPROACH to Multinational Corporate Family MeMBERS.....................................2

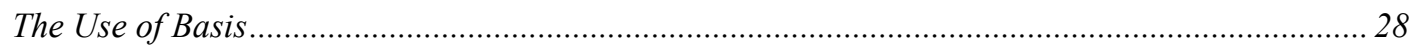

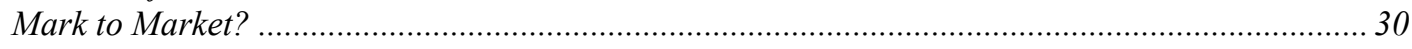

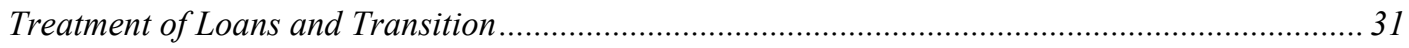

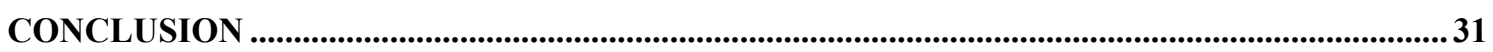

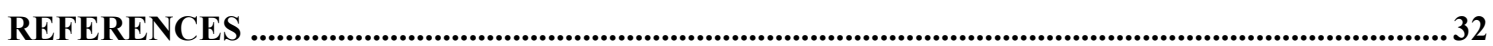


NBER WORKING PAPER SERIES

\title{
ADDRESSING THE TRANSFER-PRICING PROBLEM
} IN AN ORIGIN-BASIS X TAX

\author{
David F. Bradford \\ Working Paper 9843 \\ http://www.nber.org/papers/w9843 \\ NATIONAL BUREAU OF ECONOMIC RESEARCH \\ 1050 Massachusetts Avenue \\ Cambridge, MA 02138 \\ July 2003
}

The views expressed herein are those of the authors and not necessarily those of the National Bureau of Economic Research

(C)2003 by David F. Bradford. All rights reserved. Short sections of text not to exceed two paragraphs, may be quoted without explicit permission provided that full credit including (C) notice, is given to the source. 
Addressing the Transfer-Pricing Problem in an Origin-Basis X Tax

David F. Bradford

NBER Working Paper No. 9843

July 2003

JEL No. H20, H25, H87

\begin{abstract}
In a previous paper I described how the tax design called the X Tax would facilitate an international tax system free of many of the complexities and avoidance opportunities plaguing the existing international tax regime and also have neutrality properties generally deemed desirable. A choice must, however, be made between two basic treatments of transborder business transactions - the origin and destination principles. The destination-principle approach sidesteps the need to identify arm's length terms of transborder transactions between related business entities - the transferpricing problem. This serious problem remains in the origin-principle approach, which, however, presents fewer challenges of monitoring the flow of goods and services across borders, obviates what I call the "tourism problem" whereby people can reduce their taxes by consuming in a low-tax jurisdiction and, arguably most important, avoids transition effects associated with introduction of the tax and subsequent tax rate changes that occur in the destination approach. In this paper I explore possible special rules for transborder transactions between related parties in an origin-based system to eliminate the transfer-pricing problem.
\end{abstract}

\author{
David F. Bradford \\ Woodrow Wilson School \\ Princeton University \\ Princeton, NJ 08544-1013 \\ and NBER \\ bradford@princeton.edu
}


June 26, 2003

\section{Addressing the Transfer-Pricing Problem in an Origin-Basis X Tax David F. Bradford*}

\section{Introduction}

In a previous paper (Bradford, 2001) I sketched out how the system that I call the X Tax might be used to ameliorate a variety of problems in the existing system of international income taxation. The essential device used by the X Tax, shared with several other tax restructuring plans, is coordinated treatment of a measure of the income of companies and the earnings of workers. In the company-level tax, consumption replaces the accrual income ideal that, in principle, motivates so much of the present tax design. As a result, it is possible to exclude from taxation most financial instruments - or to neutralize their significance for tax purposes - and thereby greatly simplify and rationalize the rules.

The company-level component of the X Tax can be described as a value-added tax (VAT) of the consumption type, implemented by the subtraction method (Cnossen, 2002). As is well-known to students of international taxation, there is a fundamental choice to be made in such systems regarding the treatment of cross-border purchase and sales (McLure, 1987; Tait, 1988). In a destination-based VAT, exports, that is, sales to customers in other countries, are excluded from the domestic tax base, and imports are included - that is, not deducted in

\footnotetext{
* Princeton University, New York University, National Bureau of Economic Research, CESifo. This paper is a sequel to "Blueprint for International Tax Reform," which was prepared for the Brooklyn Law School International Tax Policy Symposium, "International Tax Policy in the New Millennium," November 9-10, 2000, and which appeared in Brooklyn Journal of International Law, 2001. To render the present paper self-contained, some portions of its predecessor are repeated here. For thoughtful comments on the issues discussed there and in this paper I would like to thank Reuven Avi-Yonah, Charles Berry, Yariv Brauner, Daniel Frisch, William Gentry, Harry Grubert, Jim Hines, Stuart Leblang, Lawrence Lokken, Paul McDaniel, Jack Mintz, Satya Poddar, James Poterba, Daniel Shaviro, Peter Sorensen, John Steines, David Weisbach, George Zodrow and two anonymous referees.
} 
determining a company's domestic tax base. In an origin-based VAT, export sales are treated like any other, that is, included in the domestic tax base; similarly, purchases from foreigners, like other purchases, are deducted. (Throughout, this paper presupposes that imports run through domestic companies. Consistent treatment of direct imports by individual consumers, e.g., returning tourists or direct sales over the Internet or by mail order, would call for appropriate institutional details that I leave largely unspecified.) As elaborated in the predecessor paper, and summarized below, various considerations favor one or the other approach to tax design. In particular, nullifying the transfer-pricing problem is a major strength of the destination principle VAT. Potentially serious incentive effects of tax rate changes in a destination-based system, correlatives of incidence effects, would, however, be avoided in an origin-principle system.

Without repeating in detail the arguments laid out in Bradford (2001), in this paper I accept that, in the design of a regime to supplant the income tax on individuals and corporations, transition phenomena, in particular, will weigh heavily in favor of keeping the origin-based treatment of cross-border purchases and sales of goods and services that characterizes the existing income tax system. This motivates the quest for a way to deal in an origin-based X Tax with the transfer-pricing problem, arising in the case of related taxpayers located in different tax jurisdictions, that is the focus of this paper.

As in the case of the predecessor paper, the object of this one is to stimulate discussion and reflection. I know of niceties I am neglecting; no doubt, there are many others of which I am unaware. A desire to avoid delay is my justification for limited citation of the work of others but extensive citation of the relevant previous works of mine (most of which are collected in Bradford, 2000). With apologies, I make no attempt to credit systematically the many, many works of others from which I have learned about all of this or to which I may implicitly respond. 


\section{$\underline{\text { The } X \text { Tax in an International Setting }}$}

The X Tax is a variant of the Hall-Rabushka (1995) Flat Tax, an example of what I have called a "two-tiered consumption tax" (Bradford 1986). Other authors have described tax systems along similar lines. I have described versions of my entry in this category in several publications (e.g., Bradford 1986, 1996a). In the interest of making this paper reasonably selfcontained, in the next section I present a brief description that neglects matters such as treatment of governments, charitable contributions, and the like.

\section{$\underline{\text { Basic X Tax structure }}$}

The X Tax consists of two components: a business tax and a compensation tax. Under the business tax, all businesses (regardless of legal form) are liable for tax at a single rate on the difference between proceeds from sales and purchases from other businesses. (I mention a qualification to this description below.) In addition, payments to workers are deducted. Except as they are also businesses, individuals are taxed only under the compensation tax, the base of which consists of payments for labor services. Unlike the business tax, the compensation tax is levied at graduated rates, with a zero bracket amount and some set of higher rates on larger amounts received, up to a top rate that is the same as the business tax rate. In addition, there could be an earned income tax credit, as under the current system.

Importantly for ease of administration, financial transactions are excluded from both business and compensation tax bases. In the ordinary case, transactions such as borrowing and lending, issue and repurchase of stock, payment and receipt of dividends, and the like, do not enter the calculation of the taxable base. In the helpful terminology of the Meade Committee (Institute for Fiscal Studies 1978), this is an R-Base ("real" transactions, as opposed to "financial" transactions) tax. (Financial institutions present special problems, which I neglect in 
this paper. For some details and some possible solutions to those problems, see Bradford 1996b.)

The idea would be to adjust these parameters to raise the needed revenue and achieve the desired degree of progressivity of the system. This is not the context in which to develop what might be required to mimic the present system's progressivity. To have something concrete in mind, however, I would guess we could approximate the progressivity of the current U.S. income tax system with a rate of business tax of 28-30 percent, which would also be the top rate of compensation tax.

If we neglect the deduction of payments to workers, the business tax component of this system constitutes, in the jargon of the tax trade, a value-added tax of the consumption type, implemented by the subtraction method. This is a great help to thinking about the links among tax systems in a world of national X Taxes. For, provided the rate of tax is the same and neglecting administrative details, a value-added tax of the subtraction type is essentially equivalent to a value-added tax of the invoice-and-credit type, a tax institution with which there is a great deal of experience.

Under the invoice-and-credit method, the selling firm pays a tax on all sales, noting the amount of tax on the sales invoice. A taxable firm making a purchase is allowed a credit against tax liability of the amount of tax shown on the invoice. The effect is that a sale from one business to another gives rise to simultaneous payment of tax by the seller and equal credit against tax for the buyer. There is no net tax paid to the government until the point of sale to a buyer other than a taxable firm, generally the public. The invoice-and-credit method valueadded tax thus gives rise to exactly the same flow of revenues to the government as does a 
subtraction-method value-added tax or a retail sales tax, with the proviso that the same goods and services are subject to tax at the same rate.

The fact that the X Tax allows a deduction for payments to workers (taxed progressively via a graduated rate schedule at the individual level) and would presumably include an earned income tax credit does not fundamentally change the story from an economic perspective, even though it may do so from a legal perspective. The system can be understood as a subtractionmethod value-added tax, combined with a system of transfers based on earnings for purposes of adjusting the vertical distribution of net burdens (Bradford 1987).

\section{Extension to an International Setting}

The building blocks of the X Tax are business firms. We can think of it as a tax that consolidates transactions among some set of companies, with the base consisting of the net flows of goods and services from that set of companies. In principle, there is considerable room for choice about the exact definition that places a company within or outside the taxable circle. For present purposes, however, I imagine rules rather like the ones now used to determine the liability for value-added taxes (Lokken (2001) provides a discussion). Given such conventions, no distinction is made between domestic and foreign companies. All companies operating in the United States, for example, are treated alike.

\section{Two General Approaches: Origin- and Destination-Based Taxes}

In general, in the purely domestic context, a sale from a company to a customer that is not another company is subject to tax, and a purchase from a customer that is not another company is not deductible from the tax base. In the international setting, however, there are two main options for the treatment of transactions with customers ("sales to abroad") and suppliers ("purchases from abroad") who are in another tax jurisdiction. 
Under most value-added tax systems, no tax is charged on exports, that is, sales to abroad; imports, purchases from abroad, are subject to tax. Not charging value-added tax on exports corresponds to excluding sales to abroad from the $\mathrm{X}$ Tax base (so they are not subject to current tax). Corresponding to charging value-added tax on imports is denying a deduction for business purchases from abroad in the X Tax. The result is a "destination-based" tax, the idea being that the tax is based on the aggregate value of goods and services consumed in the country in which it is levied. Sales destined for another country are excluded from the base of the exporting country; imports destined for a country are included in the importing country's base.

The alternative is to include in the domestic business tax base sales to abroad and to allow a deduction for purchases from abroad. The result is an "origin-based" tax, the idea being that the tax is levied on the aggregate value of goods and services produced in the country in which it is levied. Understandably, these two approaches seem very different to the lay person. In view of the strong equivalence between these two forms of tax, however - they are economically essentially the same, apart from transition effects associated with rate changes and apart from the transfer-pricing problems that are the focus of this paper - it is clear that we must be careful in basing intuitions on the destination and origin labels. Distinctions between the two approaches encountered in policy debates, especially regarding effects on exports, are often wrong (Feldstein and Krugman, 1990).

Economic Equivalence between the Approaches: The Basics

A numerical illustration will remind readers of the sense in which the two approaches are economically equivalent. Suppose the world consists of two countries, the United States and France, between which trade is currently and has in the past been exactly balanced (so the value of goods and services exported from the one exactly equals the value of goods and services 
imported in return, period by period). Both countries produce a basic consumption good, say corn, which sells for $\$ 1$ per bushel. In addition, computers are produced in one of the countries, say the United States, selling for $\$ 1000$ each.

In the illustrative equilibrium, $1 \mathrm{~m}$ of the computers are sold by U.S. companies to buyers in France for a total value of $\$ 1 \mathrm{~b}$. Companies in France export to U.S. companies $1 \mathrm{~b}$ bushels of corn at $\$ 1$ each. The United States has an origin-based X Tax (so with no adjustment at the border) with a business tax rate of 25 percent. For purposes of this and other such exercises in this paper, we can ignore the compensation tax or assume it is levied on all earnings at the business tax rate and withheld by the companies. So the situation is transactionally equivalent to a 25 percent value-added tax of the consumption type.

Suppose in the illustrative situation computers are produced without any inputs of labor or other materials. The tax paid by the computer sellers on their export sales is $\$ 250 \mathrm{~m}$ and the owners of the companies get to keep $\$ 750 \mathrm{~m}$. The outlay of $\$ 1 \mathrm{~b}$ for the import of corn by relevant companies gives rise to a deduction of $\$ 1 \mathrm{~b}$ and the resale to U.S. customers to an inclusion of $\$ 1 \mathrm{~b}$ for no net tax. In France, let us suppose, there is no company tax; the $\$ 1 \mathrm{~b}$ paid for the corn is paid in turn to owners of farms, to French workers and perhaps to the French government (in taxes on owners and workers), who together spend a total of $\$ 1 \mathrm{~b}$ for the imported corn.

In the alternative case, suppose that the United States employs a destination-based tax. That is to say, firms are allowed to exclude the export sales from their X-tax calculations but may not deduct the amount paid to foreign suppliers for imports. The set of prices in the United States and France that we stipulated to prevail in equilibrium under the origin-based tax cannot characterize equilibrium under the destination-based tax. Under the former set of prices, 
exporting computers from the United States to France would be highly profitable (which is why people naturally think that a shift to such a tax would stimulate exports), while the U.S. importer of corn would suffer losses. We can, however, readily specify other sets of prices that will, however, give rise to exactly the same activities as we observed in the origin-based tax world.

For example, if the price level (not just the price of corn) in France were lower by 25 percent, the former equilibrium conditions would be realized. In that case, the price of a bushel of corn in France would be $\$ 0.75$, instead of $\$ 1.00$. A computer would sell for $\$ 750$, instead of \$1000. Unspecified in the example, the nominal wage in France would have to be lower, too, by 25 percent, so the real wage rate would be the same in the two situations. We know that, with these prices, the French farmers will happily supply the same quantity of corn to the U.S. companies as in the former case, and that U.S. demand for French (plus U.S.) corn would be the same, because $\$ 0.25$ per bushel in tax is added to the price in the destination-based system. The U.S. computer makers are happy to accept the $\$ 750$ offered by the French buyers, even though computer still sell for $\$ 1000$ in the United States, since the sale is not included in the $\mathrm{X}$ Tax base and hence yields the same amount as a domestic sale after the $\$ 250$ tax. The U.S. Treasury still collects $\$ 2.5 \mathrm{~b}$ in tax; owners of U.S. computer companies still get $\$ 7.5 \mathrm{~b}$ in earnings that they can still spend on computers and corn at the original terms.

Note that, in view of the equivalence between the outcomes in these two situations, we would want to describe them in international trade statistics as being the same. This would be accomplished by measuring both exports and imports, not at what the U.S. exporter or importer receives or pays, but at their value in the U.S. market. Under the origin-based tax system, these two are the same but in the destination-based system, they differ by the applicable U.S. tax. 
In this example, I used a lower price level in France to generate the economic equivalence between the two tax regimes. I could as readily have used a higher price level in the United States. Alternatively, some readers may find it easier to think of a variation in the exchange rate between different currencies used in the two countries, with no difference in the general price levels between the two tax regimes. So, suppose under the initial, origin-based situation, one dollar (\$1) buys ten French francs (Ffr 10). Computers sell for Ffr 10,000 each and corn for Ffr 10 a bushel. If, in the alternative, the United States has a destination-based tax, all of the real opportunities in the system are the same if the exchange rate is Ffr 13.33 to the dollar (13.33 less 25 percent of 13.33 equals 10). The exporter of a computer from the United States receives Ffr 10,000 , which he exchanges for $\$ 750$. Since this sale is not subject to tax, the exporter keeps the whole amount; the after-tax result is the same as for a $\$ 1000$ sale to a domestic customer. The U.S. importer of a bushel of corn pays $\$ .75$ at the 13.33 to 1 exchange rate. When the bushel is sold for $\$ 1$ there is no deduction, so $\$ .25$ in tax is paid; the net proceeds just cover the cost of the import.

The point to take away from this exercise is the basic economic equivalence of the two approaches once in place and with the same tax rate when prices are determined at arm's length. The choice between these two rules for treatment of trans-border sales does, however, have important implications, mostly relating to transitional incidence and incentives but also relating to administrability, especially in situations with transactions across borders among related companies.

\section{Administrative Properties}

Bradford (2001) is centrally concerned with the way an international tax system based on universal use national X Taxes could resolve a variety of problems that vex the present 
international income tax regime. I will not rehearse those matters here except to say that the key feature of the system contributing to its properties is its grounding in cash-flow accounting for sales and purchases of goods and services only (with, in general, exclusion of financial transactions from the tax base). In the standard subtraction-method value-added tax, all that is required to calculate a firm's tax base is cash-flow information about real transactions - sales less purchases from other businesses. It is important to note here that, for reasons that are briefly sketched below in connection with transition in the international context, I have come to the conclusion that a modification to this accounting system, to provide instead for something like conventional business income accounting for "real" business assets (inventories, equipment, structures, land, etc.), would ameliorate - in principle, eliminate - incentive and incidence effects of tax rate changes. To keep the consumption-tax economic properties of the system, a deduction would be provided for the current cost of capital, calculated as the product of an appropriate interest rate and the real business asset basis (Bradford 1998). (To be clear: No deduction is allowed for interest expense.)

Maintaining the consistency of ignoring financial transactions is important, since the major simplifications achieved by the $\mathrm{X}$ Tax are due to the fact that financial transactions are excluded. This eliminates a host of intractable problems in the world of finance (Bradford 1995). For ordinary business tax accounting, it means no inclusion of interest or dividends received (and thus no rules to distinguish between them), no deduction for interest paid, and myriad related changes in accounting, eliminating an equally large host of tax complexities. To mention one prominent problem that would disappear: No special rules are required for capital gains. Business assets are taxed on a cash-flow basis (perhaps as modified per my remarks 
above); transactions in financial assets and liabilities, and associated financial flows, such as payments of dividends and interest, are out of the base.

These administrative advantages extend to the international version of the system. New administrative problems are, however, introduced by the border adjustment in the case of the destination-based system. The exclusion of sales to abroad requires monitoring methods to assure that the payments in question really come from foreign purchasers (rather than domestic consumers). The disallowance of deduction for purchases from abroad requires monitoring incoming travelers at the borders (since it has the effect of subjecting imports to tax), as is done by customs inspectors at present. Different from import tariffs, however, is the treatment of imports by businesses; since a denial of a deduction is involved, there is no need to monitor business imports. This might be implemented by requiring businesses to justify deductions by providing the tax identification numbers of suppliers; a foreign supplier would not have a U.S. tax identification number (Lokken 2001).

The disadvantage of monitoring the border is offset by a major plus of a destinationbased tax, its elimination of the transfer-pricing problem. The need to value purchases and sales among related domestic and foreign companies is a perennial problem in the existing income tax. The problem is greatly magnified by the ever-growing importance of intangible property in the generation of profit and the rapid growth of intra-firm trade (Gordon and Hines, 2002). Since the proceeds of a sale to a foreign customer are not in the destination-based X Tax base, the price that related partners may use to account for the transaction has no impact on the tax base. The same holds for an import from abroad. The price does not matter because there is no deduction.

Under the origin-based system, by contrast, there is no need to police the borders for imports (apart from customs requirements). This property becomes especially important when 
we take into account the possibility that consumers may cross borders to do their consuming. I call this the "tourism problem," with the caveat that the term may seem to imply it is confined to cross-border shopping on temporary excursions. It applies as well to the situation of a U.S. individual who times consumption to take place in a low-tax jurisdiction - for example, during retirement years - and thereby avoids the tax that would fall on a person who remained in the United States. The price of avoiding the need for monitoring the borders is, however, to bring back the transfer-pricing problem.

\section{$\underline{\text { Supernormal Returns, Measurement Issues and Transfer Pricing Problems }}$}

To illustrate some of these points in our abstract international economy, we need to change the stipulated facts. We can, for example, add capital transactions - a U.S. investor might lend $\$ 1 \mathrm{~m}$ to a French borrower. To postpone dealing with time more systematically, suppose the loan and repayment (without interest, because the time is so short) occur between 8:00 am and noon of the one day in the model. Such financial transactions are ignored in the $\mathrm{X}$ Tax so this round trip transaction would have no tax consequences, direct or indirect. A slightly more interesting transaction could, however, have indirect tax consequences: The French borrower agrees to pay off the outcome of a $\$ 1 \mathrm{~m}$ bet in the French stock market, which is open from 8:00 am until noon. At noon, the financial arrangement is wound up, with the U.S. investor having made a profit or a loss, relative to the $\$ 1 \mathrm{~m}$ put up at 8:00 am. This result will ultimately - for illustrative purposes, I am assuming immediately - result in an increase (if the investment is a winner) in imports to the United States from France, or a decrease (if the investment is a loser). In a destination-based tax, the result is a change in U.S. tax revenues, since imports are not deducted but sales to the public (which are affected) are subject to tax. In that world, the U.S. fisc shares in the fortunes of U.S. financial investments abroad (since they affect 
consumption in the United States). In the origin-based system, the changes in sales to the public that result from the working out of the illustrative financial position are matched by changes in deductions for imports, so there are no indirect tax consequences.

The expected return on a financial investment will generally embody a risk premium (which, as illustrated by insurance, could be negative). In the example, it may be that the expected payoff to the financial investment in France (net of the invested amount) is positive and we might say it incorporates the expectation of a "supernormal return." This expected supernormal return is subject to U.S. tax indirectly, if the system is on a destination basis. It is ignored if the system is on an origin basis. There is, presumably, no policy significance to this tax difference in this case. The U.S. tax stake in the foreign investment simply compensates for the portion of the risk taken on by the U.S. fisc. (For a discussion of the general issues involved see, for example, Kaplow 1994,Bradford 1995 or Zodrow 1995).

A different form of "supernormal return" is at issue in the classic transfer-pricing situation. To adapt our illustration for the purpose, suppose the patent for producing the computers in our example is owned by a U.S. company. Since a computer sells for $\$ 1000$, and all that is required to produce one is the patent right, that right will also sell (at arm's length) for \$1000. Now, instead of having the U.S. company export computers, suppose it exports to a French company the rights to produce 1 million computers for a licensing fee of $\$ 1000$ per unit. In this fact situation, the tax consequences and exchange rate or price level outcomes under the alternative regimes are the same as in the earlier example of the export of computers from the United States, simply substituting U.S. export of license rights (a "service") for export of computers. 
If the licensing transaction as described is at arm's length, that is, between parties with opposing interests in its terms, this example presents no fresh administrative problems. New issues may arise, however, if, as is typical, the payoff to the licensor were to take the form of a share of the profits from the sale of computers by the French licensee, or a royalty per unit sold in the future. What I, at least, think of as the conceptually "correct" accounting for this transaction would be to value the sale of license rights at $\$ 1 \mathrm{~b}$, which is of direct tax consequence only in the origin-based system. The subsequent actual payoff to the U.S. owner of the rights would be treated as a financial transaction, with no direct tax consequences in either system. In the case of an uncertain return, the indirect tax consequences of the financial portion of the transaction would be different under the origin- and destination-principle regimes, as discussed above.

But the actual terms of the transaction may not reveal this conceptually correct amount. Using as an alternative the cash-flows attributable to the licensing arrangement (royalties), for example, will give a different result. (If one can ignore timing issues, the tax consequences of this approach will be an economically equivalent result if the arrangement is at arm's length.) There are no direct tax consequences, in any case, in the destination-based system; in the originbased system, the direct tax liability will be proportional to the payment, of whichever form. In particular, the risky form may include a "supernormal return" element.

Where, however, the French company is, in fact, owned by the U.S. computer company, the licensing transaction is functionally internal to the firm, whatever may be the legal structure of the companies. In the origin-based system, the terms of the transaction matter. Now there are two problems. The first is converting the possibly contingent terms of the transaction (for example, a royalty per computer) into the arguably correct equivalent certain current amount. 
This is no different from the same problem for arrangements reached at arm's length. Much more serious, and also sometimes described as involving supernormal returns, is determining appropriate arm's lengths terms, whatever their form. Since the transaction is effectively within a single entity, its terms on the books of the two nominally separate companies are referred to as "transfer prices." Because transfer prices need have no significance apart from their use in determining tax or other regulatory consequences, they can and will be adjusted to optimize those consequences. The check on this optimization in the tax context is to require the prices, or the terms of transactions more generally, to be those that would be reached at arm's length. If the two companies are dealing in bushels of corn, it is a straightforward matter to determine the requisite arm's length prices. When, however, they are dealing in complex goods and services, as in the example of a license to sell a particular form of computer, the arm's length standard leaves a very wide range of choice for the taxpayer companies. (Because the economic justification for ownership extending across national borders may be synergies internal to the firm, arm's length terms may not even be well defined.) This is the transfer-pricing problem in tax administration.

To illustrate, suppose the U.S. parent knows that computers can be sold for $\$ 1000$ but this is not a fact easily discerned by the tax authorities. The U.S. parent therefore licenses the wholly owned French company to sell computers for a royalty of $\$ 500$ per computer, or $\$ 0.5 \mathrm{~b}$ for the run of $1 \mathrm{~m}$ computers in the illustrative transaction. In a destination-based U.S. tax system, these terms are of no significance, since the sale of services to the foreign company are not taken into tax directly. The payoffs to such foreign investments are, however, reflected indirectly in the tax base, when they affect imports of goods and services (which are sold in the United States subject to tax but support no deduction). In the origin-based system, the royalty 
determines the U.S. tax base of $\$ 0.5 \mathrm{~b}$ in this case, compared to the $\$ 1 \mathrm{~b}$ tax base that would have obtained under arm's length terms. The profit obtained by the French subsidiary can then be repatriated to the parent company as a dividend on equity, a financial transaction that is not taken into the tax base, directly or indirectly, under the standard rules.

Under the nonstandard rules that I suggest below to eliminate, or at least to minimize, the opportunity for related companies to game an origin-based X Tax through such transfer-pricing devices, the transactions between parent and subsidiary are aggregated (so dividends are treated as sales). Dealing with changing tax rates over time requires an additional feature. To illustrate it requires introducing time explicitly.

\section{Transition and Tax Rate Changes over Time}

A particularly important set of issues bearing on the choice between origin- and destination-basis approaches, involving both allocative efficiency and equity, is raised by transition. The obvious transition is from the existing tax regime to the $\mathrm{X}$ Tax regime. Since the treatment of international business in the existing income tax system is essentially on an origin basis (sales to abroad are counted in income and purchases from abroad are deducted), it is the potential shift to a destination-based tax that poses the distinctive problems. This, in turn, is most easily analyzed in terms of a switch from an origin- to a destination-based X Tax. This transition amounts to an increase in the tax rate "forgiven" on exports and imposed on imports from zero (under the origin-basis tax) to the full $\mathrm{X}$ Tax business rate (under the destination-based tax). Furthermore, the problems associated with this transition are repeated any time there is a change in the business $X$ Tax rate in a destination-, but not in an origin-, based tax.

A similar phenomenon is encountered in the choice I have mentioned above between a cash-flow business tax and an economically equivalent tax that uses income accounting for 
business assets, including a separation of capital and current transactions, with an allowance of a deduction for the capital tied up replacing the immediate expensing of capital outlays. The capital cost deduction would be determined by multiplying the capital in the business, as measured by basis, by an appropriate rate of interest. I think it will help understanding of the international tax problem to review the transition issue in this purely domestic context. Generic Features of Transition to this Type of Tax

Transition to a consumption type tax, such as the $\mathrm{X}$ Tax, from an income type tax with current accrual accounting, such as the existing system, raises significant issues of incidence and efficiency. Most of those engaged in tax policy debates are familiar with the major point: Shifting from accrual to pure cash-flow accounting imposes a one-time tax on "old capital" or, more precisely under income tax accounting conventions, "existing basis" in the nonfinancial assets of businesses (Bradford, 1996a; Pearlman, 1996; Hall, 1996; Zodrow, 2002). Whether this is fair in the context of a major tax restructuring is debatable (Kotlikoff, 1996; Shaviro, 2000). It is not debatable that it presents significant incentive problems, since taxpayers can mitigate the burden of the transition impact, perhaps significantly, by selling their assets to increase consumption in anticipation of the change in regimes. Both equity (accepting the premise that it is unfair to impose such a transition burden on taxpayers) and efficiency considerations support the adoption of the income style accounting for business activity that I briefly alluded to above. (If all that were involved were a one-time change in the applicable X Tax business tax rate, from zero to some fixed level, the same result would be obtained with cash-flow accounting by permitting immediate expensing of business asset basis in the new regime.) 


\section{The Tomato Juice Problem}

I like to use the following numerical example to illustrate this problem of transition from an accrual business income tax to a cash-flow business tax (Bradford 1996a). In that case, consider a retailer who purchases $\$ 10,000$ worth of canned tomato juice on December 31 . The next day, the cash-flow business tax replaces an accrual income tax. The retailer sells the tomato juice for an apparently break-even sum of $\$ 10,000$. This sale is taken into income. Under an accrual income tax, there would be an offsetting deduction of the $\$ 10,000$ cost of goods sold, reflecting the outlays for the inventory in the previous year. But under the cash-flow tax, only current-year outlays are deductible. So the retailer is stuck with the full amount of the tax on his inventory. The extra tax remains, regardless of the character of the economic adjustment to the changed regime (for example, it is unaffected if there is a general price level increase in the amount of the new tax; see Bradford 1996a).

To work out the incidence and allocational effects of the transition, we need to think through how people would behave to avoid the burden. The traditional approach treats the introduction of the cash-flow tax as a completely unanticipated event (Feldstein, 1976). In that case, the transition effect (the tax on the inventory of tomato juice) is completely borne by the taxpayer who happens to own the assets affected. At the other extreme, if the introduction of the tax is anticipated far in advance, no one will be foolish enough to hold assets across the boundary of introduction of the cash-flow accounting unless doing so is rewarded by an appropriately high real reward. In the case of the tomato juice example, presumably, businesses would hold inventory from December 31 to January 1 of the transition year only under the expectation that consumers will pay a premium for the service provided by the retailer - as an alternative to buying their tomato juice before the transition and storing it in their kitchen 
cabinets. The generic point is that an anticipated change to the cash-flow from an income tax regime - or of an increase in the tax rate under a cash-flow regime - cannot in the absence of transactions costs impose any particular tax burden on the owners of the assets subject to the transition penalty. Instead, it will impose a tax disincentive on pre-transition investment with returns extending into the post-transition period - driving up the pre-tax rate of return and driving down the interest rate applicable to commitments that cross the temporal boundary between the two regimes. There would then be a positive incentive to invest right after the transition - driving up the interest rates for commitments extending forward from the transition boundary. The incidence effects are those of the peculiarly time-varying rate of tax on the return to investment, with its associated impact on efficiency.

The incidence of an unanticipated decline in a cash-flow tax rate, and the incentive effects of an anticipated decline in the tax rate, are simply the opposite of those for an increase in the tax rate.

\section{Using Income-Style Accounting to Avoid the Problem}

One of the strengths of true accrual income as a tax base is its insensitivity to changes in the rate of tax. Income tax accounting principles incorporate this idea in their insistence on associating income with particular years - rules that would measure income over several years but give effect to the same discounted tax, given a constant tax rate, are therefore generally shunned.

This property can be turned to the service of a consumption-type tax by making use of the familiar concept of basis in real assets. In practice, this would mean maintaining something like the present system of accounting for depreciable assets and inventories instead of the expensing of capital outlays of the classic cash-flow consumption-type tax. To preserve the 
consumption base as the effective principle, an allowance would be provided for the cost of capital deployed in the business, calculated as the product of an appropriately chosen rate of interest and basis (Bradford 1996a). (This should not be confused with a deduction for interest paid; there would be neither taxation of nor deduction of interest payments in the system.)

The ideal of this approach, as of theoretical Haig-Simons income accounting, is mark-tomarket valuation of assets. An increase in value of an asset during the year would be added to the tax base in that year and also added to the basis of the asset, eligible for the interest allowance and recoverable as a deduction upon disposal of the asset. Boadway and Bruce (1984) may have been the first to describe the theoretical underpinnings of this system, which was actually briefly put into practice in Croatia (Rose and Wiswesser, 1998). Its implementation presents a number of challenges worth closer examination that we can undertake here. Two such challenges, however, merit mention. The first is the determination of the appropriate rate of interest to use in the calculation of the cost of capital used in the business. The idea is that a business owner should be indifferent between the depreciation plus interest on basis that goes with an investment and immediate write-off, taking due account of the possibilities that financial markets will present to convert one form of cash flow to another. The second is the system's call for information on accruing changes in asset values. This requirement has long been recognized as an Achilles heal of the accrual income tax standard. In this connection it is significant that, unlike for an income tax, accuracy in the timing of deductions is unimportant so long as the rate of tax is constant. The cost of capital allowance compensates for postponing deductions, and reduction of the allowance offsets the advantage of any acceleration of deductions, relative to the mark-to-market standard, that the rules may allow. (Throughout this paper I abstract from an 
important aspect of capital accounting, the need to allow for inflation in rendering comparable amounts at different dates.)

The importance of matching the basis of assets to market value is confined to conditions of changing tax rate. To illustrate, suppose inventory with market value $\$ 100$ is carried on a company's books with a basis of $\$ 50$. If the tax rate is going to increase between the present and the next period, it is advantageous to realize now, so that the $\$ 50$ excess of basis over market will be taxed at the present, rather than the next-period rate. The opposite holds if the basis of the asset is $\$ 150, \$ 50$ over current market value. Then it will pay to postpone realization. These accelerations and postponements translate into systematic distortions of investment. The workability of imperfect asset accounting in the $\mathrm{X}$ Tax context is premised on the likelihood that tax rate changes will be relatively slow, infrequent and hard to predict and on the fact that realizing the market value of typical business assets is not as easy as in the case of inventories. The Fundamental Problem of Rate Changes in a Destination Tax

The choice between origin- and destination bases for the $\mathrm{X}$ Tax regime raises similar problems. We can get a feel for them by imagining what would be involved in making a switch from an origin- to a destination-basis tax.

Since the issues here are all about timing, and not about production of different goods in different countries, we can examine them in a stripped-down model with just a single good (corn) that can be produced in either of the two countries (United States and France) and that can be consumed or invested in capital in either of the countries. In the example at the beginning of the paper we took as a condition a situation of balanced trade. Now we are interested precisely in the possibility of unbalanced trade, so we need to introduce the element of time, which I do by specifying a two-period world. As in the earlier example, we assume that there is an X Tax (or 
subtraction-method consumption tax on goods and services) in the United States only. Any taxes in France use some other approach. The U.S. tax may be of either the destination- or origin-type.

Start with an origin-basis tax, say at a rate of 25 percent; the price of corn in the two countries must be the same, say $\$ 1$ per bushel. In France, the wage rate is also $\$ 1$ (some other tax is used to pay for government); in the United States the wage rate is $\$ .75$. In the first period, the good is exported and imported in some quantities, and at the end of the day there exist various borrowing, lending, and wealth-holding (stocks of corn) situations, some crossing the national border.

We need not go through all the details; it suffices to illustrate the problem created by a shift in the U.S. tax from origin to destination basis between the first and second period. Between the first and second period, shift to allow a border adjustment for the U.S. 25 percent tax. Now, to equilibrate trade in the single commodity, the price has to change in the United States or France. Suppose it drops in France and stays at \$1 in the United States; stocks of corn in France now sell for $\$ .75$ per bushel, instead of $\$ 1$. For someone planning to consume in France, this is no problem. But there is a problem for a U.S. resident, owning a stock of corn in France but desiring to consume at home.

Thus, suppose I, a U.S. resident, own a stock of corn in France. I got my stock by sending some corn to a French consumer in the first period. In general, I will have earned a return on my stock, so it will be more than I sent over in the first period. We need not spell out this detail either. Before the destination tax, I could import my stock to the United States without tax. In the new situation, when I want to bring my corn home to the United States, I 
must pay a tax of $\$ .25$ per bushel, based on its U.S. market price of $\$ 1$ per bushel. So I only get to consume three quarters of what I had anticipated at the time of my export to France.

The impact of a shift in regime from an origin to a destination basis is analytically the same as an increase in the rate of a desination-based tax from zero to 25 percent. More generally, the incidence phenomenon sketched here would accompany any change in the rate of a desination-based tax. (A drop in the rate would imply a gain for my illustrative claimant on France.) As in the analogous case of an increase in the rate of a cash-flow tax in a purely domestic setting, in the international context incidence effects - gains and losses based on saving or portfolio commitments established before the policy shift - depend on whether the change is, as in the example, completely unanticipated. If it is completely anticipated, the incidence effects must be built into the anticipated returns. In the example, I would certainly not have exchanged my corn in the first period for a claim on an equal amount of corn in France, to be redeemed (with an ordinary rate of return) in the second period. Either the actuality of a change in tax regime (or tax rate) or the risk that it might happen would, in theory at least, greatly influence the international capital market.

An unanticipated shift from an origin-based tax to a destination-based tax would impose a one-time tax at the X Tax rate on the net claims of U.S. taxpayers on the rest of the world. If the net claims are positive, the tax is a loss to the U.S. claimants and a gain to the U.S. fisc. If the net claims are negative, the tax would be negative (and there would be a cost to the U.S. fisc). Corresponding to these incidence effects would be incentive/allocative effects to the extent the change in policy is anticipated, and there would be ongoing incentive/allocative effects from the ongoing risk of tax rate changes. 
It would be useful to know how important, quantitatively, are the incidence and efficiency effects of transition/rate changes. What one may think of as the direct impact incidence - since it is the product of the tax rate change and the net claim on foreigners (which could be positive or negative) - is sensitive to the size of that net claim. If the foreign claims on the United States and the U.S. claims on foreigners are equal, a completely unexpected tax change would not have U.S. tax revenue consequences (at least in terms of present discounted value). Still, U.S. owners of claims on foreigners would lose and foreign owners of claims on U.S. residents would gain from an increase in the tax rate/shift from origin- to destination-based tax. Furthermore, the incentive effects of anticipated rate changes do not depend upon the balance of claims. It is hard to image that an anticipated change from 0 to, say, 28 percent would not have quantitatively significant impacts.

It is true that European economies have somehow made the transition to destinationbased value-added taxes of 15-20 percent without obvious consequences of the type I have described but it is not clear that anyone has looked for such consequences. Furthermore, it is well known that the European value-added taxes, at least initially, substituted for turnover taxes of broadly similar economic character. One could describe their introduction as a rationalization of a destination-type value-added tax structure. Consequently, without having done the hard work to assess the proposition, I would surmise that the issue raised here is quantitatively significant.

In most of the examples I chose to look at a change from an origin- to a destination-based tax advisedly. Since the treatment of sales and purchases of goods and services in the U.S. income tax is today on an origin basis (business sales to foreign customers are counted in gross income and purchases from abroad are deducted, perhaps on a delayed basis if on capital 
account), adopting an origin-based X Tax would presumably have relatively small incidence and allocation effects of the sort described above.

\section{$\underline{\text { A Remedy for the Transfer-Pricing Problem in an Origin-Based X Tax }}$}

In view of the advantages of the origin-based approach (transition problems, including ongoing transition problems associated with tax rate changes, much less than in the destinationbased approach; monitoring the borders not necessary; no "tourism" problem), a method of reducing or eliminating the transfer-pricing problem would be of considerable value. In what follows I suggest such a method. The ideas are preliminary, and have not been subjected to the acid test of the search by clever tax advisors to game the proposed system. In my view, however, the approach merits close study.

Cash-Flow Accounting for Foreign Subsidiaries: The Domestic Installment-Sale Analogy

The cross-boundary transfer-pricing problem is analogous to the problem of taxing the domestic sale to a consumer (or a nontaxable entity) of an ordinary commodity, say an automobile, on an installment basis. In the standard X Tax accounting (as under a conventional value-added tax), interest received is not included in tax. By bundling the sale of the car with the credit sale contract, specifying a low price on the car but a high rate of interest on the loan, a company can keep the cash flow from the buyer constant but convert it in part into a nontaxable form. A similar logic is at work when the company sells a car to its foreign subsidiary for an artificially low price. In this case the payment in return takes the form of a financial transaction (a dividend) that is not subject to X Tax. (I use "foreign subsidiary" to stand for "related party" here. The key question is whether transactions involve the sort of opposition of interests that we summarize in the arm's length characterization. Implementing the approach I am about to outline would require a specification of these conditions.) 
McLure and Zodrow (1996) regard this problem as sufficiently serious to merit aggregating all transactions of companies, financial and real, in determining the cash-flow business tax base, thereby implementing an "R+F" ("real plus financial") company tax, in the terminology of the Meade Committee (Institute for Fiscal Studies 1978). A more narrowly targeted remedy in the installment sale case is to require cash-flow treatment of the bundled transaction (Bradford 1996a,b). So if the financing is not organized at arm's length, the seller is taxed on all payments received for the car, however labeled and at whatever time. The characteristic exemption of interest in a consumption-based tax means that the seller will be indifferent between arm's length terms and the bundled terms.

Once we are in this world, however, there are fresh incentives when the tax rate is not constant. By charging a low price for the car and high interest rate on the loan, the seller can move tax base from the present into the future. If the future tax rate is lower than the present, this is advantageous. Conversely, if the tax rate is going up in the future, by charging an abovemarket price for the car and a below-market interest rate on the loan, the seller can concentrate the tax base in the current period. Protection against such manipulation can be implemented by a requirement that the car sales price be an arm's length price. A possible alternative or additional requirement, that I do not pursue here, would be arm's length conditions on the loan that is embedded in the installment contract. This may seem to leave us with the problem we started with. But typically the stakes will be much lower (and with the possibility of rate changes either up or down, gaming the system is more difficult), so the importance for tax administration of getting the price "right" will be less. 


\section{Applying the Approach to Multinational Corporate Family Members}

The case of related-party transactions across national jurisdictional boundaries in an origin-basis tax is similar to the installment-sale example in involving conversion of a taxable sale to a nontaxable financial payments. I suggest a two-part approach to this problem. First is bundling of the goods and services and financial flows through aggregation of the transactions between related parties. Second, the familiar income tax concept of basis is deployed to inhibit the manipulation of financial flows to exploit tax rate changes over time.

To use the basic bundling approach of the installment sale example, when Ford U.S. (FUS) sells motors to Ford Canada (FC), its wholly owned subsidiary, all payments from FC to FUS with respect to these engines would be taken into U.S. tax, as representing current or deferred payment for the motors. The analysis goes through as before, including the U.S. tax system's stakes in getting the nonfinancial price (the price of the motors) "right" when the tax rate is changing through time.

There is a fresh difficulty, however. It will generally not make sense to isolate a single sale and its consequences. When FUS sells motors to FC at a below-market price, the payoff is higher future dividends from FC to FUS, which are the result of all the operations of the two companies, not confined to the transactions involving the motors. The suggested remedy is to treat the entire financial relationship on a bundled basis. Any financial transfer from FUS to FC would be deducted and any payment from FC to FUS would be included in U.S. tax.

To illustrate, if FUS sets up FC by transferring $\$ 1$ b to FC, the amount would be deducted from the U.S. tax base. When, subsequently, FC sends a dividend back to FUS, the amount would be included in the U.S. tax base. Now suppose that FUS sells FC \$1m worth of motors for an artificial transfer price that means FUS is paid only $\$ 700 \mathrm{k}$, which is subject to U.S. tax. 
This reduces the FUS tax base by $\$ 300 k$, compared with a transaction at arm's length. But the implication is an increase in subsequent dividends from FC to FUS by $\$ 300 \mathrm{k}$ (in present value the dividends may take place in the future). With constant tax rate, the result is a wash - no gain from the manipulation of the transfer price.

The problems that arise when the tax rate is not constant are, however, more serious than in the case of the illustrative installment sale. By large transfers to and from a foreign sub, a U.S. parent could exploit even small year-to-year differences in the U.S. tax rate. A possible remedy for this problem, as in the analogous domestic situation discussed above, is to follow principles of timing underlying the existing income tax, in which income is assigned to particular years so the taxpayer does not have a choice in this regard.

\section{$\underline{\text { The Use of Basis }}$}

To return to the purely domestic context, the $\mathrm{X}$ Tax would use capitalization rules for ordinary business assets more or less along present lines. The difference from an income tax would be the allowance of a deduction for the normal return on basis. In the international context, the analogous reasoning would apply to an equity position in a foreign subsidiary. Now a transfer from parent to subsidiary gives rise, not to a current deduction but to an addition to parent's basis in the subsidiary. A transfer from the subsidiary to parent - that is, a dividend would be deducted from the parent's basis.

The basis device with respect to transfers between parent and subsidiary protects against essentially unlimited exploitation of tax rate variation across time. As in the installment-sale case, there remains the potential to exploit tax rate variation via transfer prices in the "real" domain. To illustrate: FUS sells FC \$1m worth of motors for an artificial transfer price that means FUS is paid only $\$ 700 \mathrm{k}$. This reduces the FUS tax base by $\$ 300 \mathrm{k}$, compared with a 
transaction at arm's length. To simplify, suppose the interest rate is zero. Next year, FC sends home to FUS the profit of $\$ 300 \mathrm{k}$ made on the sale of the motors (presumably built into their assembled cars). If the tax rate is lower in the second year than in the first, FUS gains from this set of transactions. The required remedy is the same as in the present system, to attempt to assure the price of the motors is the arm's length price. The fact that the stakes in the proposed approach are in the intertemporal difference in the tax rate, not in timing (because of the interest allowance on basis) or the entire rate, should help to make it workable.

We can check that the approach works for relations between a foreign parent and U.S. sub: Suppose Farma Switzerland (FS) sells its products through a wholly-owned U.S. subsidiary, Farma U.S. (FUS). The basic rule is that a transfer of funds from FS to FUS is included in the U.S. tax base of FUS, and a transfer from FUS to FS is deducted from the U.S. tax base of FUS. For the same reason discussed above, these inclusions and deductions would be run through basis accounting but that is primarily directed at the problem of time-varying tax rate. We can more easily trace the logic of the system by using the straight inclusion and deduction approach. To simplify, assume the interest rate is zero (and that investments earn exactly the market rate of interest). If FS transfers \$1m to FUS and earns the going rate of return, FUS will be liable for tax on the $\$ 1 \mathrm{~m}$ inbound investment and will get a deduction of equal discounted value when it returns the investment, plus profit, to FS.

Now suppose FS sells $\$ 1 \mathrm{~m}$ worth of cosmetics to FUS for $\$ 1.3 \mathrm{~m}$. The immediate impact is a deduction of $\$ 1.3 \mathrm{~m}$ from the FUS U.S. tax base. But a further impact is a reduction, by $\$ .3 \mathrm{~m}$, of the deduction for profit remitted by FUS to FS, compared to the accounting at the arm's length price. So there is no tax benefit from manipulating the transfer price. 
As in the example of the U.S. parent and Canadian sub, because there would be an advantage from this sequence of transactions in the event of time-varying U.S. tax rate, there is a U.S. tax system stake in getting the transfer price right. The possibility of time-varying tax rates also means that the treatment of transfers would run through basis. In the example, when If FS transfers $\$ 1 \mathrm{~m}$ to FUS, there will be no current U.S. tax consequences but FUS will have a negative basis (i.e., liability) in the amount of $\$ 1 \mathrm{~m}$. When there is a positive rate of interest, FUS will be charged for holding the negative basis (possibly by additions to the negative basis). When FUS transfers to FS, there is a conceptual deduction but this is replaced by an addition to basis in the amount of the rebated profit.

\section{Mark to Market?}

The potential to profit from timing of transactions (sale of assets in the simple domestic setting) is eliminated by true mark-to-market accounting. The use of conventional depreciation accounting is necessarily accepted for ordinary business assets because market values are not available. (Reminder: With constant tax rate, these timing issues are of no significance in a present value sense.) In the international setting, the analogy would call for adjusting basis in foreign subsidiaries by the amount of accounting profit or loss. In present-system terms, there would be no deferral of foreign income or loss. Unrepatriated earnings of a subsidiary would be taxed currently to the parent but added to basis. (Losses of a subsidiary would result in a current deduction by the parent and subtraction from basis.) Because basis earns an interest allowance, there would be no present-value significance to getting this exactly right over time spans with constant tax rate. Getting it right is significant only with changing tax rate. 


\section{Treatment of Loans and Transition}

Among details to be resolved in implementation of the suggested system is the identification of the transfers between related parties that are brought into the system and treatment of positions of firms prior to its introduction. I can do no more here than suggest approaches to these issues. As to the first, transactions labeled "debt" between parent and subsidiary could be used to exploit differences between the domestic and foreign tax rates. As in the case of the domestic installment sale example, erring on the side of bringing too much into the comprehensive accounting (so taxing all payments for the car) is, in principle, a safe course. The result is a wash if the transaction is on arm's length terms. Questions of monitoring and administrative costs would probably dominate in evaluating alternative rules.

As for the second issue, in the transition to a purely domestic $\mathrm{X}$ Tax, companies would carry basis in their real business assets into the new system. Exactly analogously, a U.S. company's basis in ownership claims to affiliates (and perhaps for debt claims, depending on the treatment chosen for related-party debt), treated like basis in real assets. For a foreign-owned U.S. company, the relevant basis would be negative, reflecting the equity claim of the foreign parent.

\section{$\underline{\text { Conclusion }}$}

Although I have not dwelled on it here, there is no denying the simplicity advantage of the straight cash-flow treatment of sales and purchases of goods and services in the purely domestic context, or of the destination-principle extension to international transactions. The main justification for considering the modification in the domestic rules, involving capital accounts for businesses and a deduction for the capital thus tied up, is to neutralize the system with respect to changes in the business tax rate over time, especially the change that would occur 
as the new system is introduced. The same justification applies to the attempt describe in this paper to use an analogous approach to implementing origin-principle treatment of sales and purchases that cross international boundaries.

The main challenge in implementing the origin approach is dealing with transfer pricing - the ability of companies to manipulate the terms of transactions among commonly owned entities located in different countries, so as to locate the tax base where the rate of tax is lowest. The basic tax planning tool is to manipulate the boundary between real (taxed) and financial (normally not taxed) transactions. The remedy suggested here builds on an analogy with an installment sale to a consumer in the purely domestic context, which presents the opportunity, through non-arm's lengths terms of the financial part of the contract, to convert taxable to tax free payments. In the case of commonly owned domestic and foreign companies, the line is between domestic and foreign tax jurisdictions, and the details of the aggregation, involving the use of capital accounts and a corresponding deduction for business capital, are somewhat more involved.

There is no doubt that the approach I have outlined is more complicated than the destination principle's exclusion of goods and services transactions. On the other hand, the fact that it relies on basically familiar concepts from income tax accounting is a strength. If successful, it would open the possibility for achieving the advantages of the origin-based approach without its principle disadvantage.

\section{$\underline{\text { References }}$}

Auerbach, Alan J., and David F. Bradford, "Generalized Cash-Flow Taxation," Journal of Public Economics, forthcoming. 
Boadway, Robin, and Neil Bruce, “A General Proposition on the Design of a Neutral Business Tax,” Journal of Public Economics, (XXIV) 1984, pp. 231-239.

Bradford, David F., Untangling the Income Tax, Cambridge, MA: Harvard University Press, 1986, x, 386 pp.

Bradford, David F., "On the Incidence of Consumption Taxes," in Charls E. Walker and Mark A. Bloomfield, eds., The Consumption Tax: A Better Alternative, Cambridge, MA: Ballinger, 1987, pp. 243-261; revised version published as "What Are Consumption Taxes and Who Bears Them?" Tax Notes, Vol. 39-3, April 18, 1988, pp. 383-391.

Bradford, David F., "Fixing Realization Accounting: Symmetry, Consistency and Correctness in the Taxation of Financial Instruments," Tax Law Review, (L-4) Summer 1995 (appeared February, 1997), pp. 731-785.

Bradford, David F., Fundamental Issues in Consumption Taxation, Washington, DC: AEI Press, 1996a. (This is an expanded version of "Consumption Taxes: Some Fundamental Transition Issues" in Michael J. Boskin, ed., Frontiers of Tax Reform, Stanford, CA: Hoover Institution Press, 1996, pp. 123-150.)

Bradford, David F., “Treatment of Financial Services under Income and Consumption Taxes," in Henry J. Aaron and William G. Gale, eds., Economic Effects of Fundamental Tax Reform, Washington, DC: The Brookings Institution, 1996b, pp. 437-464.

Bradford, David F., "Transition to and Tax Rate Flexibility in a Cash-Flow Type Tax" in James Poterba, ed., Tax Policy and the Economy, Volume 12, Cambridge, MA: The MIT Press, 1998, pp. 151-172.

Bradford, David F., Taxation, Wealth, and Saving, Cambridge, MA: MIT Press, 2000, xix, $540 \mathrm{pp}$. 
Bradford, David F., "Blueprint for International Tax Reform," Brooklyn Journal of International Law, (XXVI-4) 2001, pp. 1449-1463.

Cnossen, Sijbren, 2002. "Evaluating NRST from a VAT Perspective", in: George R. Zodrow and Peter Mieszkowski (eds.), United States Tax Reform in the 21st Century, Cambridge University Press, Cambridge.

Feldstein, Martin, 1976b. “On the Theory of Tax Reform," Journal of Public Economics 6 (1-2, July-August): 77-104.

Feldstein, Martin and Paul Krugman, 1990. “International Trade Effects of Value-Added Taxation," in Assaf Razin and Joel Slemrod (eds.), Taxation in the Global Economy (Chicago: University of Chicago Press).

Gordon, Roger H. and James R. Hines, 2002. "International Taxation," in Alan J. Auerbach and Martin Feldstein (eds.) Handbook of Public Economics, Volume 4 (New York: North Holland).

Hall, Robert E., 1996. "The Effects of Tax Reform on Prices and Asset Values," in James M. Poterba (ed.), Tax Policy and the Economy, Vol. 10 (Cambridge: MIT Press), pp. 7188.

Hall, Robert E., and Alvin Rabushka, The Flat Tax, 2nd Ed, Stanford, California: Hoover Instituion Press, 1995.

Institute for Fiscal Studies, The Structure and Reform of Direct Taxation: the Report of a Committee Chaired by Professor J.E.Meade, London: George Allen \& Unwin, 1978. Kaplow, Louis, "Taxation and Risk Taking: A General Equlibrium Perspective," National Tax Journal, (XLVII-4) December 1994, pp. 789-798. (an earliere version, issued as 
NBER Working Paper No. 3709, Cambridge, MA: National Bureau of Economic Research, May, 1991, includes more precise, formal derivations).

Kotlikoff, Laurence J., 1996. "Saving and Consumption Taxation: The Federal Retail Sales Tax Example," in Michael J. Boskin (ed.), Frontiers of Tax Reform (Stanford: Hoover Institution Press), pp. 160-80.

Lokken, Lawrence, “Marking Up the Blueprint,” Brooklyn Journal of International Law, (XXVI-4) 2001, pp. 1493-1508.

McLure, Charles E. Jr., 1987. The Value Added Tax: Key to Deficit Reduction? (Washington DC: American Enterprise Institute).

McLure, Charles E., Jr., and George R. Zodrow, “A Hybrid Approach to the Direct Taxation of Consumption," in Michael J. Boskin, ed., Frontiers of Tax Reform, Palo Alto, CA: Hoover Intstitution Press, 1996, pp. 70-90.

Pearlman, Ronald A., 1996. "Transition Issues in Moving to a Consumption Tax: A Tax Lawyer's Perspective," in Henry J. Aaron and William G. Gale (eds.), Economic Effects of Fundamental Tax Reform (Washington, D.C.: Brookings Institution Press), pp. 393-427.

Rose, Manfred, and R. Wiswesser, "Tax Reform in Transition Economies: Experiences from the Croatian Tax Reform Process of the 1990s," in: P.B. Sorensen, ed., Public Finance in a Changing World, London: MacMillan Press, 1998, 257-278.

Shaviro, Daniel, 2000. When Rules Change: An Economic and Political Analysis of Transition Relief and Retroactivity (Chicago: University of Chicago Press).

Tait, Alan A., 1988. Value-Added Tax: International Practice and Problems

(Washington DC: International Monetary Fund). 
Zodrow, George R., 1995, "Taxation, Uncertainty and the Choice of a Consumption Tax Base," Journal of Public Economics 58 (2, October): 257-65.

Zodrow, George R., 2002, Transitional Issues in the Implementation of a Flat Tax or a National Retail Sales Tax, in: George R. Zodrow and Peter Mieszkowski (eds.), United States Tax Reform in the 21st Century, Cambridge University Press, Cambridge. 